\title{
OVICIDAL AND REPELLENT EFFECTS OF SOME SPICE POWDERS AGAINST THE CALLOSOBRUCHUS CHINENSIS L. AND C. MACULATUS (F.)
}

\author{
Shah H.A. Mahdi* \\ Department of Zoology, University of Rajshahi, Rajshahi 6205, Bangladesh
}

\begin{abstract}
The ovicidal and repellent effects of 11 spice powders against the pulse beetle Callosobruchus chinensis L. and C. maculatus (F.) (Coleoptera: Bruchidae) on stored chickpea and black gram, respectively was investigated. The spice powders of black cumin, black pepper, cinnamon, clove, coriander, cumin, green cardamom, large cardamom, nutmeg, red pepper and Trigonella were used throughout the experiment. The data were recorded on oviposition after 30, 60 and 100 days and repellent activity after 1 to 5 hours of treatment doses of 25 and $37.5 \mathrm{mg} / \mathrm{g}$ spice powders, which were applied with chickpea and black gram seed on C. chinensis L. and C. maculatus (F.), respectively. Minimum number of oviposition was observed in black pepper, clove and cinnamon treated pulses, while maximum number was recorded in control treatments. The ovicidal activity of the spice powders was in the order of black pepper $>$ clove $>$ cinnamon $>$ nutmeg $>$ black cumin $>$ cumin $>$ green cardamom $>$ red pepper $>$ coriander $>$ large cardamom > Trigonella $>$ as control for C. chinensis L. and black pepper $>$ clove $>$ cinnamon $>$ nutmeg $>$ black cumin $>$ cumin $>$ green cardamom $>$ red pepper $>$ coriander $>$ Trigonella $>$ large cardamom $>$ as control for C. maculatus (F.). Black peeper, clove, cinnamon and nutmeg showed repellant activity against adult $C$. chinensis L., and black peeper, clove and cinnamon showed repellant activity against adult C. maculatus (F.) while the others spices did not show any repellency.
\end{abstract}

Key words: Ovicidal effect, repellant effect, Callosobruchus chinensis,

C. maculatus, chickpea, spice powders

\section{INTRODUCTION}

Pulses have a prominent place in daily diet and these are the major sources of dietary protein, minerals and vitamin-B. Among the pulses, chickpea (Cicer arietinum L.) belonging to the family Fabaceae (Leguminosae) is the fifth most important legume crop in the world. It ranks third among the world's pulse crops after dry bean and dry pea (Shukla et al. 2007). Black gram (Vigna mungo L.) is also one of the most highly prized pulses of south and south-east Asia (Gupta 2012). The pulse seeds are greatly damaged during storage due to insect attack (Sherma 1989). Among the insect pests attacking stored products, pulse beetles, Callosobruchus chinensis and C. maculatus (Coleoptera: Bruchidae) are

*Corresponding author: mahdi_ru@yahoo.com.

(C) 2016 Zoological Society of Bangladesh DOI: 10.3329/bjz.v44i1.30176 
serious pests of several pulses and widely found in stored pulses in all parts of Bangladesh (Alam 1971). They are notorious pests of black gram, chickpea, cowpea, lentil, mung, soya and haricot bean.

The damage to pulse seeds is incredibly high both qualitatively and quantitatively (Atwal 1976). There was 55 - 69\% weight loss in seed and 45.6$66.3 \%$ loss in protein substance by pulse beetle on chickpea (Gugar and Yadav 1978). It was reported that about $100 \%$ loss of pulse seeds was found due to infestation by pulse beetle (Borikar and Puri 1985). Pulse beetle being an interval feeder cannot be controlled with insecticides. These days, methods such as storage in airtight plastic or steel containers, radiation, freezing the pulses or heating them are some of the additional possibilities. Plant materials which are being traditionally used by some farmers are quite safer and don't cause any hazard while used in the stores and appear to be the most promising as grain protectants (Golob and Webley 1980). Similarly, the uses of spices are also less costly, easily available, safer and don't cause any hazard while used in the stores.

It has been shown previously that several spice powders have potential insecticidal activities against the pulse beetles (Aslam et al. 2002, Kim et al. 2003). Insecticidal effects of 11 spice powders for the control of $C$. chinenis and C. maculatus have already been reported, and among these spice powders, clove and black pepper were most effective (Mahdi et al. 2007, Mahdi and Khalequzzaman 2008). However, the oviposition and repellent activities of these spice powders against Callosobruchus chinensis and C. maculatus have not yet been precisely documented. It is relevant to mention that none of the spice plants investigated in this study is traditionally used for storage pest control in Bangladesh. Keeping these views, the present experiment was designed to investigate the oviposition and repellent activities of eleven spice powders against the commonly known pulse beetles, $C$. chinensis and $C$. maculatus.

\section{MATERIAL AND METHODS}

Culture of Callosobruchus chinensis and C. maculatus: The pulse beetles, Callosobruchus chinensis L. and C. maculatus (F.) used in experiment were collected from a private store house of Rajshahi and Chapainawabganj, Bangladesh. For continuous and huge supply of the beetles, mass cultures were maintained in the Crop Protection and Toxicology Laboratory, Department of Zoology, University Rajshahi, Bangladesh. Mass cultures were maintained in earthen pots and sub-cultures in glass jars $(500 \mathrm{ml})$ and beakers $(500 \mathrm{ml})$ with the food medium.

Preparation of the food medium: Chickpea and black gram seeds were used as food medium for C. chinensis and C. maculatus, respectively. The seeds or 
pulses were collected from the stores were disinfested by heating for 24 hours at $60^{\circ} \mathrm{C}$ in an incubator. Then the seeds were thoroughly washed with tap water to remove dusts and carefully dried under sun-light, having 13 - 14\% moisture content and stored in air tight containers.

Preparation of the spice powders: Eleven different spices, e.g. clove (Syzygium aromaticum), black pepper (Piper nigrum), Cinnamon (Cinnamomum zeylanicum), Nutmeg (Myristica fragrans), Black cumin (Nigella sativa), cumin (Cuminum cyminum), green cardamom (Elettaria cardamomum), red pepper (Caspsicum frutescens), coriander (Coriandrum sativum), methi (Trigonella foenumgraecum) and large cardamom (Amomum subulatum) were used in this experiment. The selected spices were collected from Shaheb Bazar market of Rajshahi city. The spices were air-dried and ground in an electric grinder to make a fine powder. After grinding spice power was sieved repeatedly to obtain the finest particles. The separate spice powders were kept in separate plastic containers for the further experiment.

Oviposition experiment: Recording of the data for insect oviposition was started one month after setting up the experiment and continued up to 3 months at one month intervals. The doses of 25 and $37.5 \mathrm{mg} / \mathrm{g}$ spices powder were applied with chickpea and black gram seed. The data were collected according to the following procedures. To determine the oviposition, 10 pulse grains were selected randomly from each replication, and the grain were examined for observing eggs laid by the pulse beetle, the per cent oviposition was then calculated. The data for each control set were compared to the mean of all treatments in an ANOVA test using Sigma Plot software (Version 10.0) and Microsoft Office Excel. * $\mathrm{p}<0.05$ was considered statistically significant.

Repellent activity and analysis of repellency data: Half filter paper discs (Whatman No. 40, diameter $90 \mathrm{~mm}$ ) were treated with the selected doses of 25 and $37.5 \mathrm{mg}^{-\mathrm{g}}$ of spice powders with $20 \mathrm{~g}$ seeds of chickpea and black gram for $C$. chinensis and $C$. maculatus, respectively. Ten adult insects were released in the middle treated and non-treated half of the filter paper circles. The beetle's behavior was continuously observed at every 1 hour interval until 5 hours from the release of the beetles and its position was noted at least once an hour until

$5 \mathrm{~h}$ after the release. The average of the counts was converted to percentage repellency $(\mathrm{PR})$ using the formula of Talukder and Howse $(1993,1995) . \mathrm{PR}=(\mathrm{Nc}-$ $5) \times 20$, where, Nc is the percentage of the insects on the untreated half of the circles.

\section{RESULTS AND DISCUSSION}

Oviposition of $C$. chinensis on chickpea seeds: In case of $C$. chinensis, the minimum numbers of oviposition of 5.66 and 5.33 after 30 days, 8.33 and 6.33 
after 60 days, 8.66 and 7.33 after 100 days were observed in the black pepper treated chickpea at 25 and $37.5 \mathrm{mg} / \mathrm{g}$ doses, respectively (Table 1). Highly significant differences $(\mathrm{p}<0.001)$ were found by single factor ANOVA in between and within groups at the treatments in both the doses. The two-factor ANOVA also showed the highly significant differences $(p<0.001)$ between the spices and days in different treatments. The minimum number of oviposition can be arranged in the order of black pepper $>$ clove $>$ cinnamon $>$ nutmeg $>$ black cumin $>$ cumin $>$ green cardamom $>$ red pepper $>$ coriander $>$ large cardamom $>$ Trigonella $>$ as control for C. chinensis.

Table 1. Oviposition of $C$. chinensis in different spice powders at 25 and $37.5 \mathbf{m g} / \mathrm{g}$ doses

\begin{tabular}{|c|c|c|c|c|c|c|}
\hline \multirow{3}{*}{ Spices } & \multicolumn{6}{|c|}{ Oviposition number of C. chinensis L. } \\
\hline & \multicolumn{3}{|c|}{$25 \mathrm{mg} / \mathrm{g}$ dose $($ mean $\pm \mathrm{SE}$ ) } & \multicolumn{3}{|c|}{$37.5 \mathrm{mg} / \mathrm{g}$ dose $($ mean $\pm \mathrm{SE})$} \\
\hline & 30 days & 60 days & 100 days & 30 days & 60 days & 100 days \\
\hline Black cumin & $31.00 \pm 6.24$ & $44.00 \pm 10.08$ & $47.33 \pm 2.66$ & $28.66 \pm 2.60$ & $37.66 \pm 5.04$ & $41.00 \pm 5.56$ \\
\hline Black pepper & $5.66 \pm 0.88$ & $8.33 \pm 1.20$ & $8.66 \pm 1.33$ & $5.33 \pm 1.20$ & $6.33 \pm 2.96$ & $5.33 \pm 1.45$ \\
\hline Cinnamon & $12.33 \pm 0.33$ & $17.00 \pm 3.05$ & $20.00 \pm 2.88$ & $9.00 \pm 3.05$ & $14.00 \pm 1.00$ & $18.00 \pm 1.52$ \\
\hline Clove & $8.66 \pm 2.02$ & $10.33 \pm 1.66$ & $11.00 \pm 1.52$ & $5.66 \pm 1.76$ & $10.66 \pm 2.33$ & $7.66 \pm 3.71$ \\
\hline Coriander & $48.66 \pm 7.44$ & $83.00 \pm 24.54$ & $150.00 \pm 10.58$ & $45.66 \pm 5.45$ & $67.66 \pm 6.74$ & $115.66 \pm 9.93$ \\
\hline Cumin & $38.33 \pm 4.91$ & $65.00 \pm 14.93$ & $120.66 \pm 10.58$ & $30.00 \pm 7.50$ & $40.00 \pm 8.66$ & $89.66 \pm 6.69$ \\
\hline $\begin{array}{l}\text { Green } \\
\text { cardamom }\end{array}$ & $39.00 \pm 10.69$ & $66.66 \pm 11.66$ & $133.00 \pm 27.61$ & $33.33 \pm 6.88$ & $51.00 \pm 7.81$ & $94.00 \pm 3.78$ \\
\hline $\begin{array}{l}\text { Large } \\
\text { cardamom }\end{array}$ & $48.33 \pm 11.66$ & $87.00 \pm 6.02$ & $159.66 \pm 21.05$ & $53.00 \pm 8.62$ & $83.00 \pm 18.90$ & $156.00 \pm 21.27$ \\
\hline Nutmeg & $22.00 \pm 1.15$ & $25.00 \pm 1.15$ & $29.00 \pm 2.08$ & $14.00 \pm 3.05$ & $17.00+2.88$ & $25.00 \pm 3.51$ \\
\hline Red pepper & $44.33 \pm 8.08$ & $71.00 \pm 16.65$ & $134.66 \pm 40.82$ & $38.00 \pm 9.71$ & $57.66 \pm 5.78$ & $105.00 \pm 4.61$ \\
\hline Trigonella & $52.33 \pm 4.33$ & $85.33 \pm 7.53$ & $156.33 \pm 28.81$ & $50.33 \pm 2.66$ & $80.00 \pm 10.06$ & $185.00 \pm 18.92$ \\
\hline Contol & $58.33 \pm 5.23$ & $95.00 \pm 9.01$ & $187.66 \pm 6.48$ & $54.00 \pm 5.56$ & $88.33 \pm 8.83$ & $184.00 \pm 8.32$ \\
\hline \multicolumn{7}{|c|}{ ANOVA: Single factor (between and within groups) } \\
\hline $\mathrm{F}$ & 7.98 & 8.33 & 13.65 & 11.00 & 13.66 & 47.10 \\
\hline$\underline{\mathrm{P} \text { value }}$ & $* * * \mathrm{p}<0.001$ & ${ }^{* * *} \mathrm{p}<0.001$ & $* * * \mathrm{p}<0.001$ & ${ }^{* * *} \mathrm{p}<0.001$ & ${ }^{* * *} \mathrm{p}<0.001$ & $* * * \mathrm{p}<0.001$ \\
\hline \multicolumn{7}{|c|}{ ANOVA: Two-factor (between spices and doses) } \\
\hline Between spices & $\mathrm{F}=6.84 / 11, * *$ & $* \mathrm{p}<0.001$ & & $\mathrm{~F}=6.52 / 11, *$ & $* \mathrm{p}<0.001$ & \\
\hline Between days & $\mathrm{F}=18.15 / 2, * *$ & $* \mathrm{p}<0.001$ & & $\mathrm{~F}=14.53 / 2$ & $* \mathrm{p}<0.001$ & \\
\hline
\end{tabular}

Oviposition of C. maculatus on black gram seeds: In case of C. maculatus (F.), the minimum numbers of oviposition of 1.66 and 1.33 after 30 days, 3.00 and 3.00 after 60 days, 5.00 and 4.00 after 100 days were observed in the black peppers treated black gram seeds at 25 and $37.5 \mathrm{mg} / \mathrm{g}$ doses, respectively (Table $2)$. It is obvious from the data that highly significant differences $(p<0.001)$ were found by single factor ANOVA in between and within groups at the treatments in both the doses. The two-factor ANOVA also demonstrated the highly significant variations $(\mathrm{p}<0.001)$ between the spices and days in different treatments. The 
minimum number of oviposition can be arranged in the order of black pepper $>$ clove $>$ cinnamon $>$ nutmeg $>$ black cumin $>$ cumin $>$ green cardamom $>$ red pepper $>$ coriander $>$ Trigonella $>$ large cardamom $>$ as control for C. maculatus.

Table 2. Oviposition of $C$. maculates in different spice powders at 25 and $37.5 \mathrm{mg} / \mathrm{g}$ doses

\begin{tabular}{|c|c|c|c|c|c|c|}
\hline \multirow{3}{*}{ Spices } & \multicolumn{6}{|c|}{ Oviposition number of C. maculatus } \\
\hline & \multicolumn{3}{|c|}{$25 \mathrm{mg}^{-\mathrm{g}}$ dose (mean $\pm \mathrm{SE}$ ) } & \multicolumn{3}{|c|}{$37.5 \mathrm{mg}^{-\mathrm{g}}$ dose $($ mean $\pm \mathrm{SE})$} \\
\hline & 30 days & 60 days & 100 days & 30 days & 60 days & 100 days \\
\hline Black cumin & $21.66 \pm 5.69$ & $32.66 \pm 4.91$ & $54.66 \pm 13.71$ & $12.33 \pm 3.71$ & $20.66 \pm 2.18$ & $32.33 \pm 4.91$ \\
\hline Black pepper & $1.66 \pm 0.33$ & $3.00 \pm 0.00$ & $5.00 \pm 0.00$ & $1.33 \pm 0.33$ & $3.00 \pm 0.00$ & $4.00 \pm 0.00$ \\
\hline Cinnamon & $3.33 \pm 0.88$ & $5.33 \pm 0.88$ & $8.00 \pm 0.00$ & $2.00 \pm 0.00$ & $4.33 \pm 0.33$ & $6.66 \pm 1.21$ \\
\hline Clove & $2.66 \pm 0.33$ & $4.00 \pm 0.57$ & $6.66 \pm 1.21$ & $1.33 \pm 0.33$ & $3.33 \pm 0.88$ & $5.66 \pm 0.88$ \\
\hline Coriander & $30.00 \pm 2.88$ & $55.00 \pm 8.50$ & $95.00 \pm 3.21$ & $23.33 \pm 2.84$ & $41.66 \pm 3.71$ & $71.66 \pm 13.59$ \\
\hline Cumin & $24.00 \pm 2.64$ & $35.00 \pm 8.88$ & $58.00 \pm 6.24$ & $17.33 \pm 2.41$ & $31.66 \pm 7.79$ & $30.66 \pm 3.84$ \\
\hline $\begin{array}{l}\text { Green } \\
\text { cardamom }\end{array}$ & $26.00 \pm 1.52$ & $37.33 \pm 10.34$ & $65.00 \pm 7.63$ & $19.33 \pm 0.66$ & $33.00 \pm 3.51$ & $50.00 \pm 2.31$ \\
\hline $\begin{array}{l}\text { Large } \\
\text { cardamom }\end{array}$ & $31.66 \pm 5.54$ & $60.66 \pm 10.33$ & $115.00 \pm 21.12$ & $25.00 \pm 2.51$ & $59.66 \pm 6.22$ & $99.33 \pm 6.35$ \\
\hline Nutmeg & $13.33 \pm 3.52$ & $22.33 \pm 1.45$ & $25.33 \pm 3.52$ & $8.33 \pm 3.33$ & $15.00 \pm 1.15$ & $17.33 \pm 1.21$ \\
\hline Red pepper & $27.33 \pm 3.17$ & $43.00 \pm 14.64$ & $72.00 \pm 12.85$ & $22.33 \pm 3.28$ & $35.33 \pm 7.79$ & $59.00 \pm 4.00$ \\
\hline Trigonella & $37.33 \pm 9.35$ & $59.33 \pm 4.48$ & $107.00 \pm 20.03$ & $24.33 \pm 4.81$ & $52.66 \pm 4.97$ & $82.66 \pm 4.09$ \\
\hline Contol & $38.33 \pm 6.11$ & $66.00 \pm 12.66$ & $130.00 \pm 10.06$ & $26.66 \pm 7.35$ & $75.66 \pm 15.85$ & $105.00 \pm 5.51$ \\
\hline \multicolumn{7}{|c|}{ ANOVA: Single factor (between and within groups) } \\
\hline $\mathrm{F}$ & 9.11 & 7.9 & 16.31 & 8.67 & 14.04 & 47.11 \\
\hline $\mathrm{P}$ value & ${ }^{* * *} \mathrm{p}<0.001$ & ${ }^{* * *} \mathrm{p}<0.001$ & ${ }^{* * *} \mathrm{p}<0.001$ & ${ }^{* * *} \mathrm{p}<0.001$ & ${ }^{* * *} \mathrm{p}<0.001$ & ${ }^{* * *} \mathrm{p}<0.001$ \\
\hline \multicolumn{7}{|c|}{ ANOVA: Two-factor (between spices and doses) } \\
\hline Between spice & $\begin{aligned} \mathrm{S} F & =8.15 / 11, \\
\mathrm{~F} & =1949 / 2\end{aligned}$ & $\begin{array}{l}* * * 0.001 \\
* * * 0.001\end{array}$ & & $\begin{array}{l}F=8.10 / 11, \\
F=15.39 / 2\end{array}$ & $\begin{array}{l}p<0.001 \\
p<0.001\end{array}$ & \\
\hline
\end{tabular}

Repellency in adults: Black pepper, clove, cinnamon and nutmeg showed repellant activity against adult $C$. chinensis at 25 and $37.5 \mathrm{mg} / \mathrm{g}$ for half of 90 $\mathrm{mm}$ filter paper. The data was recorded with 1 hour interval for up to 5 hours of exposure and was subjected to percentage repellency (PR) and the result is given in Table 3. In C. maculatus the significant repellency was observed for black pepper, clove and cinnamon only (Table 3). Other spices had no repellency towards the beetles. It is interesting that $C$. chinensis showed attractance to Trigonella and large cardamom, but C. maculatus showed attractance towards coriander, Trigonella and large cardamom.

Powders of five plant species, rhizomes of Acorus calamus (C), Alluum sativum, seeds of Azadirachta indica (A. juss), Carum copticum and leaves of Xanthoxylum armatum (Dc) have been tested to evaluate their effectiveness as grain protectants against Rhizopertha dominica, Sitophilus oryzae and Sitrotoga cerealella (Oliv.), and Acorus calamus showed to be the best for completely 
checking development of insect in wheat grain while Azadirachta indica and Allium sativum also showed significant results (Jilani and Hassan 1984). DonPedro (1985) examined the toxicity of powdered sun-dried orange and grapefruit peels (4.00 and $5.62 \mathrm{~g}$ ) admixture with cowpea gains (100 g) to Callosobruchus maculatus and Dermestes maculatus, and reported high doses of citrus powders depress progeny development of these species. Sweet flag rhizome powder was studied by mixing it with cowpeas grain and found high insecticidal activity and checked progeny emergence in the beetle, Callosobruchus analis (Jilani at al. 1988).

Table 3. Per cent repulsion values of the different spice powders against $C$. chinensis and $C$. maculatus adults

\begin{tabular}{|c|c|c|c|c|c|c|c|c|c|c|c|}
\hline \multirow{3}{*}{ Spices } & \multirow{3}{*}{$\begin{array}{l}\text { Doses } \\
(\mathrm{mg} / \mathrm{g})\end{array}$} & \multicolumn{10}{|c|}{ Per cent repulsion $P R=(N c-5) \times 20$} \\
\hline & & \multicolumn{5}{|c|}{ C. chinensis } & \multicolumn{5}{|c|}{ C. maculatus } \\
\hline & & $1 \mathrm{~h}$ & $2 \mathrm{~h}$ & $3 \mathrm{~h}$ & $4 \mathrm{~h}$ & $5 \mathrm{~h}$ & $1 \mathrm{~h}$ & $2 \mathrm{~h}$ & $3 \mathrm{~h}$ & $4 \mathrm{~h}$ & $5 \mathrm{~h}$ \\
\hline \multirow[t]{2}{*}{ Black pepper } & 25.00 & 90.00 & 90.00 & 90.00 & 90.00 & 90.00 & 90.00 & 78.46 & 78.46 & 78.46 & 96.73 \\
\hline & 37.50 & 90.00 & 90.00 & 90.00 & 69.73 & 78.46 & 90.00 & 90.00 & 73.57 & 73.57 & 90.00 \\
\hline \multirow[t]{2}{*}{ Clove } & 25.00 & 73.57 & 78.46 & 73.57 & 90.00 & 69.73 & 69.73 & 69.73 & 66.42 & 69.73 & 69.73 \\
\hline & 37.50 & 78.46 & 78.46 & 73.57 & 78.46 & 78.46 & 58.05 & 73.57 & 63.44 & 65.55 & 69.73 \\
\hline \multirow[t]{2}{*}{ Cinnamon } & 25.00 & 66.42 & 63.44 & 66.42 & 63.44 & 60.67 & 53.13 & 55.77 & 53.13 & 55.55 & 55.55 \\
\hline & 37.50 & 66.42 & 63.44 & 66.42 & 69.73 & 66.42 & 48.45 & 58.05 & 58.05 & 55.55 & 56.77 \\
\hline \multirow[t]{2}{*}{ Nutmeg } & 25.00 & 55.55 & 58.05 & 55.55 & 55.55 & 53.13 & 58.05 & 50.77 & 39.23 & 55.55 & 39.23 \\
\hline & 37.50 & 50.77 & 58.05 & 63.44 & 66.42 & 58.05 & 41.55 & 43.85 & 46.15 & 43.85 & 39.23 \\
\hline \multirow[t]{2}{*}{ Black cumin } & 25.00 & 46.15 & 50.77 & 50.77 & 46.15 & 46.15 & 36.87 & 41.55 & 26.56 & 43.85 & 39.23 \\
\hline & 37.50 & 46.15 & 55.55 & 53.13 & 43.85 & 50.77 & 31.95 & 53.13 & 36.87 & 43.85 & 43.85 \\
\hline \multirow[t]{2}{*}{ Cumin } & 25.00 & 41.55 & 43.85 & 43.85 & 43.85 & 39.23 & 23.58 & 26.56 & 31.95 & 29.33 & 29.33 \\
\hline & 37.50 & 41.55 & 50.77 & 50.77 & 41.55 & 46.15 & 26.56 & 11.54 & 36.87 & 39.23 & 31.95 \\
\hline \multirow{2}{*}{$\begin{array}{l}\text { Green } \\
\text { cardamom }\end{array}$} & 25.00 & 36.87 & 41.55 & 39.23 & 34.45 & 36.87 & 34.45 & 36.87 & 26.56 & 29.33 & 36.87 \\
\hline & 37.50 & 36.87 & 43.85 & 41.55 & 36.87 & 34.45 & 34.45 & 36.87 & 26.56 & 29.33 & 36.87 \\
\hline \multirow[t]{2}{*}{ Red pepper } & 25.00 & 31.95 & 36.87 & 26.56 & 34.45 & 31.95 & 29.33 & 26.56 & 34.45 & 29.39 & 26.56 \\
\hline & 37.50 & 26.56 & 34.45 & 36.45 & 31.95 & 31.95 & 26.56 & 34.45 & 29.33 & 34.45 & 29.33 \\
\hline \multirow[t]{2}{*}{ Coriander } & 25.00 & 23.58 & 16.43 & 20.27 & 11.54 & 11.54 & 11.54 & 20.27 & 11.54 & -11.54 & -16.43 \\
\hline & 37.50 & 23.58 & 23.58 & 11.54 & 20.27 & 20.27 & 16.43 & 20.27 & 11.54 & -11.54 & -16.44 \\
\hline \multirow[t]{2}{*}{ Trigonella } & 25.00 & 16.43 & -16.43 & -16.43 & -16.43 & -23.58 & 20.27 & -29.33 & -29.33 & -26.56 & -34.45 \\
\hline & 37.50 & 11.54 & -11.54 & -20.27 & -20.27 & -11.54 & 16.43 & -16.43 & -20.27 & -31.95 & -31.95 \\
\hline \multirow{2}{*}{$\begin{array}{l}\text { Large } \\
\text { cardamom }\end{array}$} & 25.00 & -31.96 & -34.45 & -26.56 & -26.56 & -20.27 & -26.56 & -36.87 & -39.23 & -36.87 & -39.23 \\
\hline & 37.50 & -34.45 & -26.56 & -26.56 & -20.27 & -11.54 & -36.87 & -36.87 & -34.45 & -41.55 & -41.55 \\
\hline
\end{tabular}

The cedarwood (Juniperus virginiana), pongam oiltree (Pongamia glabra) and black pepper (Piper nigrum) extracts were found to be stronger than the standard repellent dimethyl phthalate on adults of Tribolium castaneum (Sighamony et al. 1984). In addition, seven vegetable oils viz., sunflower (Heliunthus annus), mustard (Brassica juncea), groundnut (Arachis hypogaea), sesame (Sesamum indicum), soybean [Glycine max, olive (Olea europea) and oil palm (Elaeis 
guineensis), each were applied as grain protectants of pigeonpea against the pulse beetles Callosobruchus chinensis and treatments with groundnut and palm oils at $5 \mathrm{ml} / \mathrm{kg}$ can be recommended for C. chinensis control in stored pigeonpea for approximately two months (Khalequzzaman et al. 2007).

The findings of the present investigation are in accordance with those of other workers who have previously reported that powdered spices (flower of clove, rhizome of ginger and turmeric, fruits of black and chilli pepper (Peper nigrum, Capsicum frutescens) and bulb of garlic, powdered stem of the tree Combretum imberbe and an insecticide malathion (1.5\%) mixed with cowpeas in 0.5 liter jar at $1 \mathrm{gm} / \mathrm{jar}$, against C. maculatus (Iqbal and Poswal 1995). Oviposition and seed weight loss were recorded 10 and 70 days later, respectively. Cloves and black pepper gave results which were not significantly different from those produced by malathion (Iqbal and Poswal 1995). Dried powders of clove, red and black pepper have also been reported to prevent the infestation of bruchids at dose of $25 \mathrm{~g} / \mathrm{kg}$ (Aslam et al. 2002). However, in the present investigation an attempt has been made to find out the effect of the eleven spice powders as insecticidal at doses of 25 and $37.5 \mathrm{mg} / \mathrm{g}$.

The cloves and black peppers treated pulse beetles on pulse seeds produced less number of adults of Callosobruchus spp. (Mahdi et al. 2007, Mahdi and Rahman 2008). The possible reason could be that the active components of both the spices may effect the physiological behaviour of pulse beetles, such as ovipositional activity, growth inhibition and adult mortality. The present investigations indicate the highest ovicidal effects of black pepper, clove, and cinnamon, and these finding also supported by the repellent effects of these spices (Tables 1, 2, 3). Furthermore, effects of the turmeric, Curcuma longa for insecticidal and repellent potentials against Tribolium castaneum (Herbst) give further approval of repellent activity of the spices powders (Abida et al. 2010).

The potential of powdered black pepper, clove and cinnamon in imparting acute toxicity, discouraging oviposition and show repellency to C. chinensis and C. maculatus has been demonstrated in this study. The implementation of spice powders as grain protectant may provide suitable alternative to the traditional fumigants and synthetic insecticides for the consumers as well as the smallscale farmers in countryside. However, further investigations on the chemical composition, insecticidal properties and mode of action of the spices powders are needed.

Acknowledgments: Author thanks the Chairman, Department of Zoology, University of Rajshahi for providing laboratory facilities. 


\section{LITERATURE CITED}

ABIDA, Y., TABASSUM, F., ZAMAN, S., CHHABI, S.B. and ISLAM, N. 2010. Biological screening of Curcuma longa L. for insecticidal and repellent potentials against Tribolium castaneum (Herbst) adults. Univ. J. Zool. Rajshahi Univ. 28: 69-71.

ALAM, M.Z. 1971. Pests of Stored Grain and Other Stored Products and Their Control. Agril. Inf. Service, 3 R. K. Mission Road, Dhaka, Bangladesh. 361 pp.

ASLAM, M., KHAN, K.A. and BAJWA, M.Z.H. 2002. Potency of some spices against Callosobruchus chinensis Linnaeus. J. Biol. Sci. 2(7): 449-452.

ATWAL, A.S. 1976. Insect Pests of stored grain and other stored products. In: Agricultural Pests of India and South East Asia. Kalyani Pub., New Delhi, India. pp. 389-415.

BORIKAR, P.S. and PURI, S.N. 1985. Damages and losses caused by Callosobruchus chinensis to different legumes stored in selected containers. Agric. Sci. Digest. 5: 108-110.

DON-PEDRO, K.N. 1985. Toxicity of some citrus peels to Dennestes maculates Deg. and Callosobruchus maculatus (F). J. Stored Prod. Res. 21: 31-34.

GOLOB, P. and WEBLEY, D.J. 1980. The use of plants and minerals as traditional protectants of stored products. Tropical Products Institute. G. 138: 1-32.

GUGAR, G.T. and YADAV, T.D. 1978. Feeding of Callosobruchus maculatus and Callosobruchus chinensis Linn. in green gram. Indian J. Entomol. 40: 108-12.

GUPTA S. 2012. Project Coordinator's Report. All India Coordinated Research Project on MULLaRP, Kanpur, India.

IQBAL, J. and POSWAL, M.A.T. 1995. Evaluation of certain spices for the control of Callosobruchus maculatus (Fabricius) (Coleoptera: Bruchidae) in cowpea seeds. African Entomol. 3: 87-89.

JILANI, G. and HASSAN, S.H. 1984. Studies on some indigenous plant materials as grain protectants against insect pests of stored grain. Pak. Entomol. 6: 9-14.

JILANI, G., KHAN, M.I. and GHIASUDDIN. 1988. Studies on insecticidal activity of some indigenous plant materials against the pulse weevil Callosobruchus analis (F.) (Coleoptera: Bruchidae). Pak. J. Entomol. 3: 21-32.

KHALEQUZZAMAN, M., MAHDI, S.H.A., and GONI, S.H. 2007. Efficacy of edible oils in the control of pulse beetle, Callosobruchus chinensis L. in stored pigeonpea Univ. J. Zool. Rajshahi Univ. 26: 89-92.

KIM, S.I., ROH, J.Y., KIM, D.H., LEE, H.S. and AHN, Y.J. 2003. Insecticidal activities of aromatic plant extracts and essential oils against Sitophilus oryzae and Callosobruchus chinensis. J. Stored Prod. Res. 30(3): 293-303.

MAHDI, S.H.A., HASAN, M.A. and RAHMAN, M.K. 2007. Potency of eleven spices for the control of Callosobruchus chinensis L. (Coleoptera: Bruchidae) in garden pea seeds. Bull. Bio. Sci. 5(2): 69-74.

MAHDI, S.H.A. and RAHMAN, M.K. 2008. Insecticidal effect of some spices on Callosobruchus maculatus (Fabricius) in black gram seeds. Univ. J. Zool. Rajshahi Univ. 27: 47-50.

SHERMA, S.S. 1989. Review of literature of the losses caused by Callosobruchus species (Bruchidea:Coleopetra) during storage of pulses. Bull. Grain Technol. 22: 62-68.

SHUKLA, R., SRIVASTAVA, B., KUMAR, R. and DUBEY, N.K. 2007. Potential of some botanical powders in reducing infestation of chickpea by Callosobruchus chinensis L. (Coleoptera: Bruchidae). J. Agril. Technol. 3(1): 11-19. 
SIGHAMONY, S.I.A., CHANDRAKALA, T. S. and OSMANI, Z. 1984. Natural products as repellents for Tribolium castaneum Herbst. Int. Pest Contr. 26: 156-157.

TALUKDER, F.A. and HOWSE, P.E. 1993. Deterrent and insecticidal effects of extracts of pithraj, Aphanamixis polystachya (Mcliaceae) against Tribolium castaueum in storage. J. Chem. Ecol. 19: 2463-2471.

TALUKDER, F.A. and HOWSE, P.E. 1995. Evaluation of Aphanamixis polystachya as a source of repellents, antifeedants, toxicants and protectants in storage against Tribolium castaneum (Herbs). J. Stored Prod. Res. 31: 55-61.

(Manuscript received on 5 December, 2015; revised on 15 June, 2016) 